\title{
INTERACTIVE MULTIMEDIA ENGINE MANAGEMENT SYSTEM (EMS) TO IMPROVE PRIOR KNOWLEDGE AND PROBLEMS SOLVING ABILITY
}

\author{
Komarudin and Ahmat Mukhadis \\ Universitas Negeri Malang, Malang, Indonesia \\ E-mail: komarrakha.1982@gmail.com
}

\begin{abstract}
There are three problems in teaching engineering, especially in the field of electricity, those are: (1) students are unable to read electricity wiring; (2) students do not understand the basic concepts of electricity; (3) students do not understand the basic concept of the relationship between the electrical components. The purpose of this article are: (1) to describe multimedia, especially interactive multimedia engine management systems, prior knowledge, problem-solving; (2) to describe the relationship between interactive multimedia and prior knowledge; (3) to describe the relationship between interactive multimedia and problem solving; and (4) to provide the concept of interactive multimedia engine management system. The collection of information in this article uses a literature review or library research. Problem-solving is an attempt to solve problems through highlevel thinking (high order thinking). Prior knowledge is the initial knowledge students have when entering topics with the same background. The existence of interactive multimedia or multimedia has a positive impact on prior knowledge. Some interactive multimedia research has a positive impact on the ability of problem-solving.
\end{abstract}

Keywords: interactive multimedia, prior knowledge, problem-solving

\section{INTRODUCTION}

The technician competencies are knowledge of components name, the component function, how the component works, testing the component condition, concluding the component condition, and finally repairing or replacing the component. The process to get competencies must be hierarchical [1]. The multimedia teaches students to think hierarchically. The competencies were obtained through intensive learning. Every cognitive structuring process requires visualization so that it can be recorded effectively in memory in order of meaningful learning.

Based on the author's experience while teaching in the automotive field and the study results of articles and journals found that there are three problems in teaching engineering, especially in the field of electricity, those are: (1) students are unable to read electricity wiring; (2) students do not understand the basic concepts of electricity; (3) students do not understand the basic concept of the relationship between the electrical components [2]. The state of the electrical ability of vocational education students is categorized low. These problems are caused by the absence of media that helps visualize electrical materials[3]. In the automotive field, electricity and closed component work are abstract. According toWidjanarko et al. [2], the media in schools cannot describe these concepts optimally. The visualization process needs interactive media to trigger students' memory and motivation [4] and to gain meaningful personal experiences. The visualization is obtained through meaningful individual experiences. On the other words, visualization teaching abstract concepts will be easier [5].

The problems above influence the students' competencies, knowledge, and problem-solving abilities [2]. The electrical system knowledge is very necessary when they are involved directly in the automotive field [6]. For example, when the headlight turns off, it cannot immediately be replaced, before the analysis process is carried out. In this case, the analysis process begins with (1) examination of the fuses; (2) inspection of the lead cable from the fuse to the lamp; (3) inspection of lights; (4) inspection of the conductor from the lamp to the switch; (5) switch inspection; (6) ground check. 
Based on the problem and its impact, media, multimedia or interactive multimedia are required in learning to transfer knowledge effectively and meaningfully [2]-[5], [7], [8]. Interactive multimedia are the result of a combination of technology and learning conditions. Interactive multimedia is the best technique in education, because of its ability to show many elements such as sound, images, writing, and animation together [9]. On the other hand, interactive multimedia describes the system at work and describes the conditions that are happening to the existing system in abstract vehicles. The interactive multimedia is to link between practice and theory [6].

The purpose of this article is: (1) to describe multimedia, especially interactive multimedia engine management systems, prior knowledge, problem-solving; (2) to describe the relationship between interactive multimedia and prior knowledge; (3) to describe the relationship between interactive multimedia and problem solving; and (4) to provide the concept of interactive multimedia engine management system.

\section{METHOD}

The collection of information in this article uses a literature review or library research, in the research library. The researcher's group articles according to the discussion [10]. The information in articles discusses interactive multimedia, prior knowledge, problem-solving, and the influence of interactive multimedia with prior knowledge and problems solving. More than 84 international journal articles and several books are reviewed with details 36 articles about interactive multimedia, 3articles about EMS, 5 articles about problem-solving, 8 articles about prior knowledge, 9 articles about relationship interactive multimedia with prior knowledge, 23 articles about interactive multimedia relationships with problem-solving. Based on the literature review, the author discusses providing more in-depth about interactive multimedia in improving prior knowledge and problem-solving abilities.

\section{RESULTS AND DISCUSSION}

In this section, it will be discussedabout (1)multimedia, especially interactive multimedia engine management systems, prior knowledge, and problem-solving; (2) the relationship between interactive multimedia and prior knowledge; (3) the relationship between interactive multimedia and problem solving; and (4) the concept of interactive multimedia engine management system.

Multimedia comes from the Latin word and is used to describe how to convey messages and information. Media are commonly related to newspapers, magazines, radio, TV, audiovideo programs, computers, etc.[11]. While, Multimedia is a technology that combines print, radio, television, animation, photos and other forms of illustration. The integration of various media enriches the message to be conveyed [12]. Multimedia is the way to reduce cognitive load and reduce the presence of constructional guidance. According to research reports [13], multimedia has provided many benefits including $56 \%$ greater learning opportunities, 50 to $60 \%$ better learning consistency and 25 to $50 \%$ higher content retention. Other studies also explained that the use of multimedia has provided advantages compared with conventional learning (learning without using multimedia) [14]. The type of multimedia that is widely applied by utilizing technology is interactive multimedia.

Interactive multimedia is used to describe fields of scientific research that support expression or communication through various media [15]. The interactive multimedia means that the multimedia used must be able to interact with its users, for example, if a user changes a variable in interactive multimedia then there will be a response [16].

Interactive multimedia in learning can be more effective if it is supported by scientific learning design. Interactive multimedia has long 
been used since technology and informatics emerged [17], [18].

Interactive multimedia in learning can be more effective if it is supported by scientific learning design [19], [20]. Interactive multimedia has long been used since technology and informatics emerged [21], [22]. Multimedia assists the quality of learning to be better. Figure 1 presents the interaction between the component of interactive multimedia.

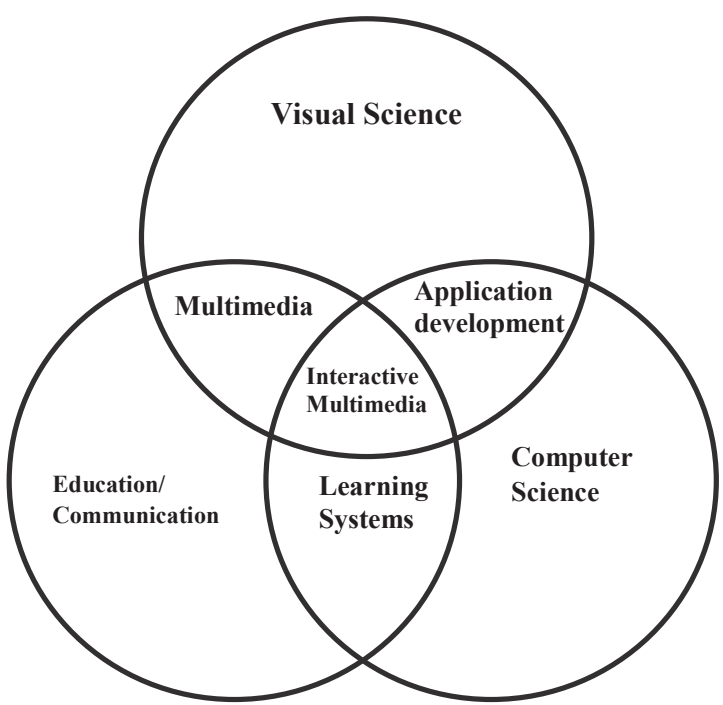

Figure 1. Interaction between Component of Interactive Multimedia

Interactive multimedia is defined as a combination of educational communication, visual science, and computer science. It is the intersection of knowledge areas that enable the creation of communication tools designed to provide information, to educate, to persuade, or to entertain [5]. Learning using multimedia is computer-based learning. [23] and [24] stated that computer-based learning increases the effectiveness of teaching and learning process, in line with research conducted by [25], [26] which states that utilization technology in learning to facilitate the learning process, the use of technology in the learning process can be used in all subject areas such as biology, even in Deniz research the use of technology is used for the history lesson. The use of multimedia technology in any form is an attempt to ease cognitive burdens [27], [28]. Multimedia is the technology that can be used without looking at the learning model [21], [29]. Learning by using multimedia is a teacher's effort in overcoming students' misunderstanding thus the information explained is related to direct practical activities then the use of multimedia is useful to avoid mistakes [30]. Sitompul $\&$ Fadilla[31] state that the use of interactive media in learning will make it easier for students to understand the content of the materials because it helps students to visualize the materials [5], [32].

Multimedia is a medium in raising awareness of students' abilities [33]. Bodemer \& Ploetzner[34] suggested the improvement of students' performance and achievement of learning objectives by using interactive multimedia. The application of multimedia provides satisfaction when attending lessons [35], [36]. While Chu et al. [36] explained that the development of multimedia encourages teachers to understand student needs and conditioning the environment or learning situation, in line with Maor [37] who states multimedia to enhance professional thinking, leading, and learning from all aspects of the presented materials. Therefore in designing multimedia, two things need to be considered namely design and pedagogy [38]. Kumpulainen \& Salovaara [39] state there are five design principles: guided activities, reflection, feedback, control, and pre-training.

Multimedia is the best media when compared to other media in line with the research of Moreno \&Mayer[40] which states that the use of multimedia is better than other media such as power points presentations. Hsiao's research is strengthened by Hsiao et al.[41] who show significant interactions from the media and students' women's questions. Lee \& Osman [3] has shown that animation and simulation using information and communication technology (ICT) can help students to visualize and therefore increase their understanding of learning abstract topics.

Zhou \& Yadav [42] mentioned that multimedia provides an efficient method for 
teaching psychomotor skills to students when entering the workforce. Cavanaugh\&Moore[43] research on the use of multimedia in learning increases student independence, maintaining discipline towards goals even without teacher intervention.

Interactive multimedia is expected to help students have basic knowledge or basic concepts in the system [44]. The use of interactive multimedia is expected to reduce cognitive load. The use of technology in learning needs to be considered to obtain an effective and efficient learning process.

In essence, interactive multimedia is a combination of 3 elements of (1) visual science in the form of images, text, videos, images or other visual forms; (2) education and communication can be a model or a way to convey knowledge; and (3) computer science, which is an agent in creating multimedia that can convey knowledge to students or receivers. Interactive multimedia is a form of multimedia in which users can interact with the multimedia.

The engine management system is the most important part of the EFI system [45]. An engine with an injection system can work properly due to the engine control module. The engine management system has 3 important components, namely sensors, engine control modules, and actuators [45]. Vocational students need to find out how the EMS because they are a candidate technician [46]. The engine management system is the most complex system of the existing system in the car, thus there will very likely be a wrong perception that occurs in the learning process so that the existence of interactive multimedia becomes an urgent need. Figure 2 presents an interactive multimedia engine management system.

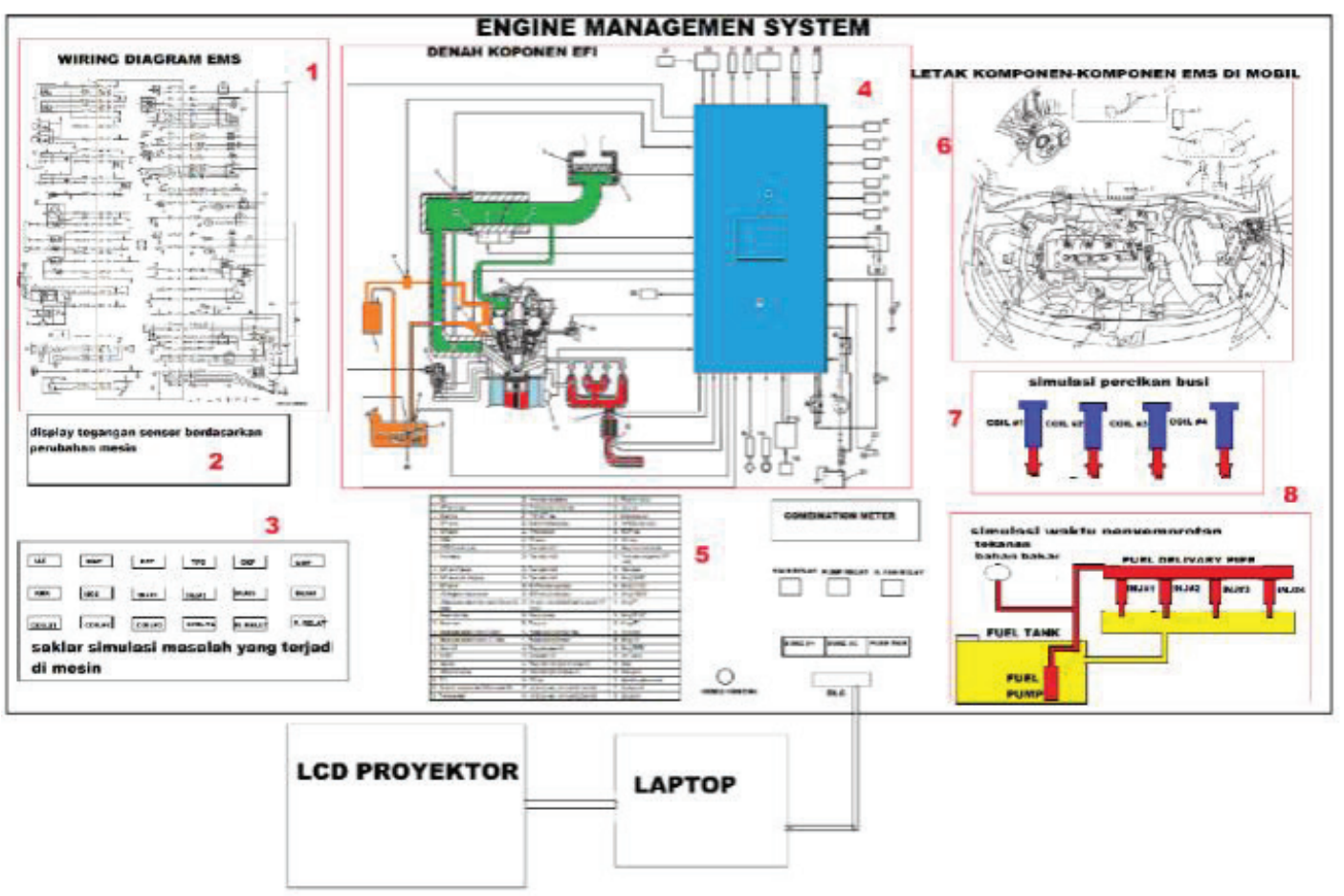

Figure 2. Diagram of Interactive Multimedia Engine Management System

The interactive multimedia engine management system helps students visualize the controlling process of the electronic fuel injection system. The interactive multimedia engine managementsystem includes a wiring image, to provide an overview of the relationship between the components of the engine management system. Each student is expected to master how to read a wiring diagram as basic knowledge in fixing issues of the engine management system so that students can have the problem-solving ability. 
The engine management system must be able to communicate with computers, laptops, and schools, thus students can identify the condition of the engine management system at each change in conditions, such as the injection at $1000 \mathrm{rpm}$ rotation, the amount of air entering, and the ignition time.Figure 3 shows illustrations in achieving goals.

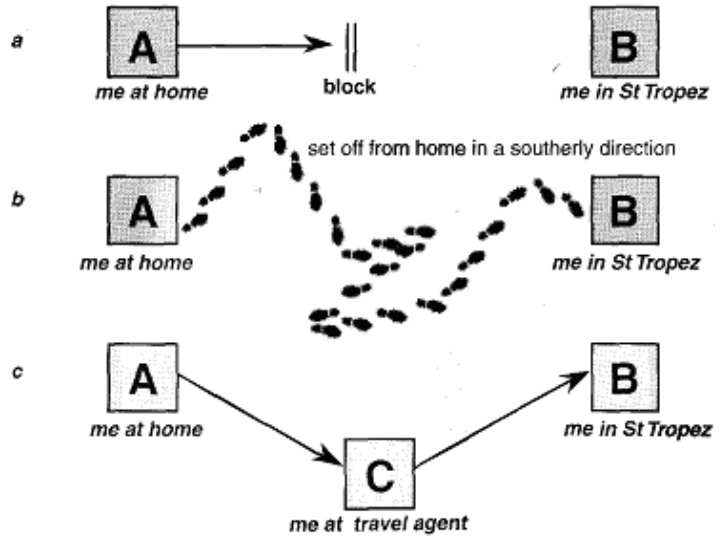

Figure 3 Illustrations in Achieving Goals

Figure 3 illustrates that each goal will have a constraint to realize, the constraint is a problem. Each problem must be solved so that it can achieve the goals that have been designed, each problem is solved in each way depends on each person who solves it. The order of thought patterns in solving problems is called problem-solving [47]. Every problem solving requires knowledge related to the problem to be solved. Problem-solving is the activity which uses high order thinking [48].

The stages of problem-solving are divided into four stages: (a) understanding the problem, (b) making a plan, (c) carrying out the plan, and (d) looking back. According to Wallas in Oliver [49] the stages of problem-solving include: (a) preparation, (b) incubation, (c) lighting, and (d) verification. In the preparation stage, researchers gather information about the problem. At the incubation stage, researchers set aside the problem of doing other activities. In the lighting stage, researchers find the key to the solution. At the verification stage, the solver checks the solution.
Problem-solving is a cognitive process, which implies conscious thinking. Educators must find the best strategy for teaching problem-solving skills. Therefore, successful instructors teach problem-solving, motivate students, and involve them to be more involved in finding accurate solutions. Various researchers agree that teaching problem solving is more efficient than traditional methods because it can produce better retention skills in the long run, and can develop critical thinking skills [50], [51]. In essence, problem-solving is an attempt to solve problems through high-level thinking (high order thinking). In the process of problem-solving required mastery of the problem.

Prior knowledge is defined variously by experts. Prior knowledge is the students'initial knowledge before entering a relevant learning environment for gaining new knowledge [52]. Prior knowledge is the overall knowledge of a person, including explicit knowledge, conceptual knowledge, and metacognitive. Prior knowledge can be expressed as knowledge possessed by students, both subject knowledge, strategic knowledge, and personal knowledge when learning new materials[53].

Prior knowledge in the form of an overall acquisition of knowledge, attitudes, and skills that students get as a result of learning activities before following the next learning process [36]. Prior knowledge is influenced by two factors, internal and external [54]. Prior knowledge influences learning activities [55]. The influence of prior knowledge includes: (1) giving effect to students when receiving new information; (2) influences the ability to organize new knowledge or information; (3) influences the ability to connect new information; (4) influences the effectiveness of the learning process [56].

Prior knowledge is very important in learning activities, to prevent misinterpretation. StrengtheningPrior knowledge is very necessary. False interpretations often occur in learning that may be one of the causes is Prior knowledge [53]. For example, learning 
electricity in vocational schools will be effective if the basics of electronics have been optimally mastered. Often students are confused when finding a fundamental problem.

Conceptual change is the process of transition from the usual way of observing, directing attention, conceptualizing, reasoning, and justifying. Students slowly transform previous knowledge to accommodate new scientific ideas. Prior knowledge tends to be a conceptual form that forms the foundation for new knowledge. Cognitive psychology and the organization of knowledge that arises through a variety of experiences and developments cause prior knowledge to be applied as a whole to improve individual abilities in certain fields [57].

In essence, prior knowledge is the initial knowledge possessed by students when entering a topic with the same background. The prior knowledge can affect the results of the learning process and it is important to avoid misperceptions about new knowledge. It is the initial scheme in shaping new knowledge.

In Song's research, Schroeder \& Cenkci[58] state that the use of multimedia has a direct impact on prior knowledge. Multimedia can help improve the quality of prior knowledge. In the study, Song et al. [59] obtained significant prior knowledge differences between the experimental class and the control class. The ability of prior knowledge is an important component in learning that must be improved through the use of multimedia [60], [61]. Each student has different abilities despite using multimedia [62]. Rias [63] states that the provision of comprehensive information has an impact on the ability of comprehensive prior knowledge as well. Learning activities are knowledge transfer processes, there needs to be a minimum of capital that students must have, namely prior knowledge. Amadieu et al. [64] suggest that prior knowledge influences computer-based learning. Multimedia is used in building prior knowledge in course places [65].
In essence, multimedia is a way of presenting information or knowledge for students in the learning process. Many studies concluded that interactive multimedia or multimedia has a positive impact on prior knowledge. This happens because by using multimedia, the information delivered is more comprehensive.

The use of computer-based multimedia influences knowledge and problem-solving abilities [66], [67] In line withSazali et al.[68]who states that the problem-solving ability of students increases when using video media during learning. By using multimedia, students' visualization of events or phenomena presented by multimedia will be formed in the brain. As stated by Mannheimer \& Amy[69] that using multimedia helps students to visualize phenomena. Hoffman \& Ritchie[70] state the use of multimedia in problem-based learning can help students solve problems. The development of problem-solving skills is done by designing problem-based learning. Problembased learning or better known as problembased learning (PBL) will be effective in achieving its objectives by utilizing multimedia [71]. In a study by Liu et al. [54] conveying that by using multimedia will be presented comprehensive instructions to guarantee the achievement of educational goals. In solving problems, comprehensive information is required so that the problem-solving process can be done precisely and quickly. Multimedia which is the result of the use of computer technology has an impact on the data presented to be comprehensive.

The application of multimedia in the learning process can improve problem-solving skills [72]-[74] with multimedia students can pay attention to the causal relationship of system components. Students who have problem-solving abilities then students have critical thinking, creativity, teamwork and presentation skills. Quality education is measured from student learning outcomes, one component of learning outcomes is problemsolving, self-efficacy [75]. 
Ryan et al. [76] illustrate that there is a strong relationship between interactive multimedia and the ability to understand problem-solving instructions, interactive multimedia is designed by integrating computer technology so that instructions will be more quickly understood. The use of interactive multimedia or interactive media in learning has several benefits, among others: (1) Interactive multimedia provides influence in the effectiveness of learning [77]; (2) the use of interactive media can minimize manufacturing errors [26]; (3) the use of interactive multimedia increases the competence of students [78]; (4) by using interactive multimedia maintaining student motivation [15]; (6) utilization of interactive media in learning encourages active students [79]; (7) interactive media can bridge basic concepts into real knowledge; (8) interactive media increases student satisfaction with learning [77]; (9) the use of multimedia for education has the advantage of providing instructions in the learning process; 10) through the use of multimedia students can visualize the process that they will do [80].

The existence of interactive multimedia is not only beneficial for students but also useful for teachers, with the presence of interactive multimedia encourages teachers to always be creative in changing teaching methods to improve student achievement [26]. Interactive media makes it easy to teach basic concepts [81]. Interactive media existence in learning has an important role, so it must be a special concern for teachers and agencies.

In essence, the ability to solve problems is important to be mastered by every student, especially vocational students majoring in automotive because when they work in a workshop they will always be treated to problems every day. Problem-solving skills are not easy to do, need good cognitive abilities. Multimedia that presents comprehensive information is very useful in forming problemsolving patterns. In some interactive multimedia, research has a positive impact on the ability of problem-solving.

\section{CONCLUSION}

Interactive multimedia is a combination of 3 elements, namely: (1) visual science in the form of images, text, videos, images or other visual forms; (2) education and communication can be a model or a way to transfer knowledge; (3) computer science, which is an agent in creating multimedia that can transfer knowledge to students or receivers. Problemsolving is an attempt to solve problems through high-level thinking (high order thinking). Prior knowledge is the initial knowledge students have when entering topics with the same background. The existence of interactive multimedia or multimedia has a positive impact on prior knowledge. some interactive multimedia research has a positive impact on the ability of problem-solving.

\section{REFERENCES}

[1] E. Masterman and Y. Rogers, "A Framework for Designing Interactive Multimedia to Scaffold Young Children's Understanding of Historical Chronology," Instr. Sci., vol. 30, pp. 221-241, 2002.

[2] D. Widjanarko, "Pemeriksaan dan Troubleshooting Motor Starter Tipe," Automot. Sci. Educ. J., vol. 3, no. 2, 2014.

[3] T. T. Lee and K. Osman, "Interactive Multimedia Module in the Learning of Electrochemistry: Effects on Students' Understanding and Motivation," Procedia - Soc. Behav. Sci., vol. 46, pp. 1323-1327, 2012, doi: 10.1016/j.sbspro. 2012.05.295.

[4] F. M. A. Khan and M. Masood, "The Effectiveness of an Interactive Multimedia Courseware with Cooperative Mastery Approach in Enhancing Higher Order Thinking Skills in Learning Cellular Respiration," Procedia - Soc. Behav. Sci., vol. 176, pp. 977-984, 2015, doi: 10.1016/j. sbspro.2015.01.567.

[5] J. L. Mohler, K. Hall, and W. Lafayette, 
"Using Interactive Multimedia Technologies to Improve Student Understanding of Spatially-Dependent Engineering Concepts," no. 1987, pp. 292-300, 2001.

[6] D. Nickchen and B. Mertsching, "Combining Mathematical Revision Courses with Hands-on Approaches for Engineering Education using WebBased Interactive Multimedia Applications," Procedia - Soc. Behav. Sci., vol. 228, no. June, pp. 482-488, 2016, doi: 10.1016/j.sbspro.2016. 07.074.

[7] D. Widjanarko, H. Sofyan, and H. D. Surjono, "Improving Students' Mastery on Automotive Electrical System Using Automotive Electrical Multimedia," Res. Eval. Educ., vol. 2, no. 1, p. 71, 2016, doi: 10.21831 /reid.v2i1.8219.

[8] Suyitno, "Pengembangan Multimedia Interaktif Pengukuran Teknik untuk Meningkatkan Hasil Belajar Siswa SMK," J. Pendidik. Teknol. dan Kejuru., vol. 23 , no. 1, pp. 101-109, May 2016, doi: 10.21831/jptk.v23i1.9359.

[9] S. Aloraini, "The Impact of Using Multimedia on Students' academic achievement in the College of Education at King Saud University," J. King Saud Univ. - Lang. Transl., vol. 24, no. 2, pp. 75-82, 10.1016/j.jksult.2012.05.002.

[10] H. M. Gothberg, "The Library Survey: A Research Methodology Rediscovered," College and Research Libraries, vol. 51, no. 6. Association of College and Research Libraries, pp. 553-559, Nov. 01, 1990, doi: $10.5860 / \mathrm{crl} 5106553$.

[11] S. Mishra and $\bar{R}$. $\bar{C}$. Sharma, Interactive Multimedia in Education and Training. Idea Group Pub, 2005.

[12] S. Kalyuga and IGI Global., Managing Cognitive Load in Adaptive Multimedia Learning. Information Science Reference, 2009.

[13] M. Neo and T. Neo, "Students ' Perceptions of Interactive Multimedia Mediated Web-Based Learning: A Malaysian Perspective," Proc. ascilite Melb. 2008, no. 1995, pp. 658-666, 2008.

[14] S. R. Manurung and D. D. Panggabean, "Development of Learning Tool of Physics Based on Interactive Multimedia Charged on " Problem
Solving " ( Mmi-Ps )to Increase Problem Solving Ability for Prospective Teachers," no. c, pp. 177-180.

[15] K. Chachil, A. Engkamat, A. Sarkawi, and A. R. A. Shuib, "Interactive Multimedia-based Mobile Application for Learning Iban Language (I-MMAPS for Learning Iban Language)," Procedia - Soc. Behav. Sci., vol. 167, pp. 267273, 2015, doi: 10.1016/j.sbspro. 2014. 12.673

[16] I. Deliyannis, Interactive Multimedia. InTech, 2012.

[17] K. S. Ivers and A. E. Barron, Multimedia Projects in Education: Designing, Producing, and Assessing. Libraries Unlimited/ABC-CLIO, 2010.

[18] J. Collins, M. Hammond, and J. J. Wellington, Teaching and learning with multimedia. Routledge, 1997.

[19] M. S. Sidhu, Technology-Assisted Problem Solving for Engineering Education: Interactive Multimedia Applicationns. IGI Global, 2009.

[20] I. Multimedia, Technology-Assisted Problem Solving for Engineering Education : Interactive Multimedia. .

[21] K. S. Ivers and A. E. Barron, Multimedia Projects in Education: Designing, Producing, and Assessing. Westport: Libraries Unlimited Teacher Ideas Press.

[22] J. Collins, M. Hammond, and J. Wellington, Teaching and learning with Multimedia. .

[23] C. H. Lu and S. F. Cheng, "Applying Computer-based Technology to Instruction for the Effectiveness of Teaching and Learning," vol. 2, no. 10, pp. 1013-1017, 2012.

[24] M. T. Al-hariri and A. A. Al-hattami, “Impact of Students' Use o Technology on Their Learning Achievements in Physiology Courses at the University of Dammam," J. Taibah Univ. Med. Sci., vol. 12 , no. 1, pp. 82-85, doi: 10.1016/j.jtumed.2016.07.004.

[25] H. Deniz and H. Cakir, "Design Principles for Computer-Assisted Instruction in Histology Education: An Exploratory Study," J. Sci. Educ. Technol., vol. 15 , no. 5-6, pp. 399-408, 2006, doi: 10.1007/s10956-006-9031-5.

[26] D. R. Manalu and D. R. P. Sitompul, "Developing Learning Media of Teaching of 8051 Microprocessor in Data Retrieval to Support the ALFHE," 
Internetworking Indones. J., vol. 9, no. 1, pp. 89-92, 2017.

[27] M. Hamdi and T. Hamtini, "Designing an Effective E-Content Development Framework for The Enhancement of Learning Programming," Int. J. Emerg. Technol. Learn., vol. 11, no. 4, pp. 131141, 2016, doi: 10.3991/ijet.v11i04. 5574.

[28] H. K. Tabbers and B. De Koeijer, "Learner Control in Animated Multimedia Instructions," no. November 2009, pp. 441-453, 2010, doi: 10.1007/s11251-009-9119-4.

[29] D. Kirsh, "Interactivity and Multimedia Interfaces," pp. 79-96, 1997.

[30] D. R. P. Sitompul and S. D. Fadilla, "An Active Learning Media of Interfacing Microcontroller 8051 To 4X4 Keypad using MCU 8051 IDE and ASM-51," ARPN J. Eng. Appl. Sci., vol. 13, no. 8, pp. 2987-2992, 2018.

[31] M. Campanella, R. Leonardi, and P. Migliorati, "Interactive Visualization of Video Content and Associated Description for Semantic Annotation," Signal, Image Video Process., vol. 3, no. 2, pp. 183-196, 2009, doi: 10.1007/s11760-008-0071-6.

[32] J. L. Mohler, "Computer Graphics for Multimedia and Hypermedia Development," vol. 10, no. 1, pp. 71-88, 1998.

[33] C. Raaff, C. Glazebrook, and H. Wharrad, "A Systematic Review of Interactive Multimedia Interventions to Promote Children's Communication With Health Professionals: Implications for Communicating with Overweight Children," BMC Med. Inform. Decis. Mak., vol. 14, no. 1, pp. 1-21, 2014, doi: 10.1186/1472-6947-14-8.

[34] D. Bodemer and R. Ploetzner, "Supporting Learning with Interactive Multimedia through Active Integration of Representations," pp. 73-95, 2005, doi: 10.1007/s11251-004-7685-z.

[35] T. K. F. Chiu, "Effects of Prior Knowledge on Mathematics Different Order Thinking Skills in Mobile Multimedia Environments," in Lecture Notes in Educational Technology, no. 9789811000256, Springer International Publishing, 2016, pp. 373-386.

[36] T. Liu, Y. Lin, and F. Paas, "Multimedia-Assisted Instruction on Pain Assessment Learning of New
Nurses : A Quasi- Experimental Study," Comput. Educ., vol. 72, pp. 328-338, 2014, doi: 10.1016/j.compedu.2013. 10.019 .

[37] D. Maor, "A Teacher Professional Development Program on Using a Constructivist Multimedia Learning Environment," Learn. Environ. Res., vol. 2, no. 3, pp. 307-330, 1999, doi: 10.1023/A:1009915305353.

[38] J. Claudet, "Integrating School Leadership Knowledge and Practice Using Multimedia Technology : Linking National Standards , Assessment, and Professional Development," J. Pers. Eval. Educ., vol. 16, no. 1, pp. 29-43, 2002, doi: 10.1023/A:1019935809057.

[39] K. Kumpulainen, H. Salovaara, and M. Mutanen, "The Nature of Students" Sociocognitive Activity in Handling and Processing Multimedia-Based Science Material in a Small Group," Instr. Sci., vol. 29, no. 6, pp. 481-515, 2001, doi: 10.1023/A:1012272119868.

[40] R. Moreno and R. Mayer, "Interactive Multimodal Learning Environments: Special Issue on Interactive Learning Environments: Contemporary Issues and Trends," Educ. Psychol. Rev., vol. 19, no. 3, pp. 309-326, Sep. 2007, doi: 10.1007/s10648-007-9047-2.

[41] C. Hsiao, M. Tiao, and C. Chen, "Using Interactive Multimedia e-Books for Learning Blood Cell Morphology in Pediatric Hematology," BMC Med. Educ., pp. 1-8, 2016, doi: 10.1186/s12909-016-0816-9.

[42] N. Zhou and A. Yadav, "Effects of Multimedia Story Reading and Questioning on preschoolers' Vocabulary Learning, Story Comprehension and Reading Engagement," Educ. Technol. Res. Dev., vol. 65, no. 6, pp. 1523-1545, doi: 10.1007/s11423-017-9533-2.

[43] A. R. Smith, C. Cavanaugh, and W. A. Moore, "Instructional Multimedia: An Investigation of Student and instructor Attitudes and Student Study Behavior," BMC Med. Educ., vol. 11, no. 1, p. 38, Dec. 2011, doi: 10.1186/1472-6920-1138.

[44] W. Wing, M. So, Y. Chen, Z. H. Wan, and Y. Chen, "Multimedia e-Learning and Self-Regulated Science Learning: a Study of Primary School Learners ' Experiences and Perceptions," J. Sci. 
Educ. Technol., vol. 28, pp. 508-522, 2019.

[45] J. Lahti, "Engine Management Systems," Encycl. Automot. Eng., 2014, doi: 10.1002/9781118354179.auto068.

[46] A. Muchta, "Prospek Kerja Lulusan Jurusan Otomotif (TKR) SMK," AutoExpose, 2017.

[47] S. I. Robertson, Problem Solving. Hove, England: Psychology Press, 2001.

[48] R. Oliver, "Using Situated Learning and Multimedia to Investigate Higher-Order Thinking," J. Interact. Learn. Res., vol. 10, pp. 3-24, 1999.

[49] E. Mayer, Multimedia Learning. Cambridge: Cambridge University Press, 2002.

[50] M. G. Voskoglou and S. Buckley, "Problem Solving and Computers in a Learning Environment," vol. 36, no. 4, pp. 28-46, 2012.

[51] P. Liljedahl and M. Santos-trigo, "Problem Solving in Mathematics Education," Egypt. Comput. Sci. J., vol. 36, no. 4, pp. 28-46, 2012.

[52] T. Hailikari, N. Katajavuori, and S. Lindblom-ylanne, "The Relevance of Prior Knowledge in Learning and Instructional Design the Relevance of Prior Knowledge in Learning and Instructional Design," Am. J. Pharm. Educ., vol. 72, no. 5, p. 113, 2008, doi: 10.5688/aj7205113.

[53] J. Roschelle, "Learning in Interactive Environments: Prior Knowledge and New Experience," in In J.H. Falk \& L.D. Dierking, Public institutions for Personal Learning: Establishing a Research Agenda, Washington DC: American Association of Museum, 1995, pp. 37-51.

[54] M. K. Akinsola, "Effects of Mnemonic and Prior Knowledge Instructional Strategies on Students 'Achievement in Mathematics," Int. J. Educ. Res., vol. 2, no. 7, pp. 675-688, 2014.

[55] K. Henderson, "The Effects of Prior Knowledge Activation on Learner Retention of New Concepts in Learning Objects," 2007.

[56] K. Lederm and I. Fallmann, "Predicting Learning Success in Online Learning Environments : Self-regulated Learning, Prior Knowledge and Repetition," Zeitschrift für Hochschulentwicklung, vol. 12, no. 1, pp. 79-99, 2017.

[57] N. L. Schroeder and A. T. Cenkci,
"Spatial Contiguity and Spatial SplitAttention Effects in Multimedia Learning Environments: a MetaAnalysis," Educ. Psychol. Rev., vol. 30, pp. 679-701, 2018.

[58] H. S. Song, A. L. Kalet, and J. L. Plass, "Interplay of Prior Knowledge, Selfregulation and Motivation in Complex Multimedia Learning Environments," $J$. Comput. Assist. Learn., vol. 32, no. 1, pp. 31-50, 2015, doi: $10.1111 /$ jcal.12117.

[59] S. Kalyuga, "Effects of Learner Prior Knowledge and Working Memory Limitations on Multimedia Learning," Procedia - Soc. Behav. Sci., vol. 83, no. 1965, pp. 25-29, 2013, doi: 10.1016/j.sbspro.2013.06.005.

[60] S. Kalyuga, Managing Cognitive Load in Adaptive Multimedia Learning. Hershey, PA: Information Science Reference, 2009.

[61] R. M. Rias, "Understanding the Role of Prior Knowledge in A Multimedia Learning Application," Australas. J. Educ. Technol., vol. 29, no. 4, pp. 537548, 2008.

[62] T. Chu, J. Wang, H. Lin, H. Lee, C. Lin, and L. Chieh, "Multimedia-Assisted Instruction on Pain Assessment Learning of New Nurses: A QuasiExperimental Study," BMC Med. Educ., vol. 19, pp. 1-8, 2019.

[63] F. Amadieu, A. Tricot, and C. Mariné, "Interacting with Computers Interaction between Prior Knowledge and ConceptMap Structure on Hypertext Comprehension, Coherence of Reading Orders and Disorientation," Interact. Comput., vol. 22, no. 2, pp. 88-97, 2009 , doi: 10.1016/j.intcom.2009.07.001.

[64] F. Calisir, M. Eryazici, and M. R. Lehto, "The Effects of Text Structure and Prior Knowledge of the Learner on ComputerBased Learning," Comput. Human Behav., vol. 24, no. 2, pp. 439-450, 2008, doi: 10.1016/j.chb.2007.01.032.

[65] S. J. Bennett and M. J. Brennan, "Interactive Multimedia Learning in Physics," Australas. J. Educ. Technol., vol. 12, no. 1, pp. 8-17, 1996.

[66] H. Melander Bowden, "Problem-Solving in Collaborative Game Design Practices: Epistemic Stance, Affect, and Engagement," Learn. Media Technol., vol. 9884, 2019, doi: 
10.1080/17439884.2018.1563106.

[67] M. Sazali, M. Alias, W. Razally, and S. Yamin, "The Effect of Using an Interactive Multimedia Courseware within a Collaborative Learning Environment on the Learning of PreAlgebra Concepts among Pre-University Engineering Students," in International Conference on Mathematics Education Research 2010 (ICMER 2010), 2010, vol. 8 , pp. 571-579, doi: 10.1016/j.sbspro.2010.12.079.

[68] J. Mannheimer and Z. Amy, "The Use of Video Cases in a Multimedia Learning Environment for Facilitating High School Students ' Inquiry into a Problem from Varying Perspectives," $J$. Sci. Educ. Technol., vol. 20, pp. 715728, 2011, doi: 10.1007/s10956-0109264-1.

[69] G. Korakakis, A. Boudouvis, J. Palyvos, and E. A. Pavlatou, "Social and the Impact of 3D Visualization Types in Instructional Multimedia Applications for Teaching Science," Procedia - Soc. Behav. Sci., vol. 31, no. 2011, pp. 145149, 2012, doi: 10.1016/j.sbspro.2011. 12.032 .

[70] B. O. B. Hoffman and D. Ritchie, "Using Multimedia to Overcome the Problems with Problem Based Learning," Instr. Sci., vol. 25, pp. 97 $115,1997$.

[71] I. Mcalpine and R. Clements, "Problem Based Learning in the Design of a Multimedia Project," Aust. J. Educ. Technol., vol. 17, no. 2, pp. 115-130, 2001.

[72] S. R. Manurung and S. Mihardi, "Improved Problem-Solving Ability after using Interactive Multimedia in Teaching of Ideal Gas," Indian J. Sci. Technol., vol. 11, no. 36, pp. 1-7, 2018, doi: 10.17485/ijst/2018/v11i36/.

[73] M. Neo, T. Neo, and G. T. Xiao-lian, "A Constructivist Approach to Learning an Interactive Multimedia Course : Malaysian Students' Perspectives Introduction," Australas. J. Educ. Technol., vol. 23, no. 4, pp. 470-489, 2007.
[74] M. Zaid, M. Zin, A. Asmadi, and N. Azlina, "Relationship Between the Multimedia Technology and Education in Improving Learning Quality," Procedia - Soc. Behav. Sci., vol. 90, no. InCULT 2012, pp. 351-355, 1877, doi: 10.1016/j.sbspro.2013.07.102.

[75] R. Zheng, "Recency Effect on Problem Solving in Interactive Multimedia Learning Recency Effect on Problem Solving in Interactive Multimedia Learning," Educ. Technol. Soc., vol. 9, no. 2, pp. 107-118, 2006.

[76] Q. X. Ryan, E. Frodermann, K. Heller, L. Hsu, and A. Mason, "Computer Problem-Solving Coaches for Introductory Physics: Design and Usability Studies," Phys. Rev. Phys. Educ. Res., vol. 12, no. 1, p. 010105 , 2016, doi: 10.1103/PhysRevPhys EducRes.12.010105.

[77] L. Al-Safadi, "The Effects of Real-Time Interactive Multimedia Teleradiology System," Biomed Res. Int., vol. 2016, pp. 1-9, 2016, doi: 10.1155/2016/ 4126841.

[78] Samsudduha, Masugiono, and Supraptono, "Automotive Science and Education Journal," Automot. Sci. Educ. J., vol. 2, no. 2, pp. 71-76, 2013.

[79] F. T. Leow and M. Neo, "Interactive Multimedia Learning: Innovating Classroom Education in a Malaysian University," Turkish Online J. Educ. Technol., vol. 13, no. 2, pp. 99-110, 2014.

[80] A. Y. W. Nicholson and Y. K. N. Johnson, "Managing the Development and Production of Interactive Multimedia Courseware in Education," Australas. J. Educ. Technol., vol. 12, no. 1, pp. 35-45, 1996.

[81] F. M. A. Khan and M. Masood, "Potential of Interactive Multimedia Learning Courseware Using Three Different Strategies in the Learning of Biology for Matriculation Students in Malaysia," Procedia - Soc. Behav. Sci., vol. 116, pp. 2521-2525, 2014, doi: 10.1016/j.sbspro.2014.01.604. 